\title{
Serotonin Neurons, Neuroplasticity, and Homeostasis of Neural Tissue
}

\author{
Efrain Charles Azmitia, Ph.D.
}

Homeostasis is the process by which the internal milieu of the body is able to maintain equilibrium in the face of constant insults from the external world. Endocrine, immune, and vascular systems play pivotal roles in adjusting internal biochemical reactions to counteract assaults from the outside. Despite the vast accumulation of data over the last 50 years, a role for serotonin in brain homeostasis has not been proposed. In this chapter I will review the plasticity and anatomy of serotonergic neurons in integrating external sensory and motor systems as well as internal endocrine, glial and vascular signals with the various cellular elements comprising neural tissue. Steroids and neuropeptides have both been shown to alter the morphology of serotonergic neurons. In turn, alterations in serotonin levels in the adult brain can change the morphology of its target cells. A pivotal role for serotonin in the homeostasis of neural tissue is consistent with the function of serotonin throughout evolution and explains the large number of biological systems, behavioral activities, and clinical diseases associated with serotonergic neurons. [Neuropsychopharmacology 21:33S-45S, 1999] (C) 1999 American College of Neuropsychopharmacology. Published by Elsevier Science Inc.
KEY WORDS: Raphe; Co-localization; Ultrastructure; Evolution; Neuropeptide; Review

\begin{abstract}
"By an apparent contradiction, it maintains its stability only if it is excitable and capable of modifying itself according to external stimuli, and adjusting its response to the stimulation. In a sense it is stable because it is modifiable-the slight instability is the necessary condition for the true stability of the organism." (W.B. Cannon 1929).
\end{abstract}

In 1948, Rapport and colleagues purified and identified a chemical 5-hydroxytrptamine (5-HT) (Rapport et al. 1948) present in serum, which had powerful effects on smooth muscle contraction. They named it serotonin. This chemical exist in nearly every biological organism studied in-

From the Department of Biology, New York University, New York, NY.

Address correspondence to: Dr. E.C. Azmitia, Department of Biology, New York University, 100 Washington Square East, New York, New York 10003-6688.

Received December 10, 1998; revised February 5, 1999; accepted February 8, 1999. cluding plants, invertebrates, and vertebrates (Garattini and Valzelli 1965; Saxena et al. 1966; Smith 1971; Fischer 1971). The wide distribution in plants and animals indicates this system is phylogentically ancient and evolved very early. Consistent with this idea, the receptors for serotonin, especially the high-affinity 5-HT1 subtype, appears to be over a billion years old (Peroutka and Howell 1994). In mammals, high levels of 5-HT are seen in gut, lung, kidney, testis, superior ganglia and brain (Twarog and Page 1953; Verhofstad et al. 1981; Gershon 1991). These issues are raised here because whatever function serotonin plays in the brain, it should be relevant to its' evolutionary history.

Despite this ubiquitous natural distribution, most functions attributed to serotonin have centered on its effects on specific neurons and distinct behavior. There are several ideas, which proposed a more general function for serotonin. Serotonin was proposed to be essential for normal mental health (Woolley 1961). This hypothesis was based on its similar structure to LSD, discussed more fully in the chapter by Whitaker-Azmitia (1999). Brodie and Shore (1957) proposed a meta- 
bolic role for serotonin in the neuronal activity of the brain. In their hypothesis, norepinephrine and serotonin modulated opposite systems in the brain based on Hess's (1954) concept of the functional integration of the autonomic system with the CNS. Serotonin was the modulator of the trophotrophic system, which integrates behavioral patterns that are recuperative in nature. This was considered a recessive system, which normally functions during sleep or hibernation. Using Golgi-stained brainstem material, a close relationship is seen between the raphe reticular neurons and blood vessels (Scheibel et al. 1975). Based on purely anatomical grounds, these neurons were proposed to function either as a chemoreceptor or a mechanoreceptor, although a neuroscretory role of a bioactive substance into the vascular system from these raphe neurons could not be ruled out. We now propose that the raphe neurons are a key component of neural tissue homeostasis be- cause they are plastic and respond to a variety of neuronal and non-neuronal factors. Our dynamic concept encompasses the concepts of Woolley (1961), Brodie and Shore (1957), and Scheibel et al.(1975). The serotonin neurons evolved as general regulatory system to respond to external stimuli by continually modifying themselves. The fluctuations in serotonin levels are broadcast throughout the brain and serve to dynamically integrate and stabilize CNS structure and function.

\section{THE BRAINSTEM RAPHE NUCLEI: ORGANIZATION AND CHEMICAL LOCALIZATION}

Serotonin neuroanatomy is, at first examination, an enigma. The serotonergic raphe nuclei form a chemically homogenous reticular group of neurons which ex-

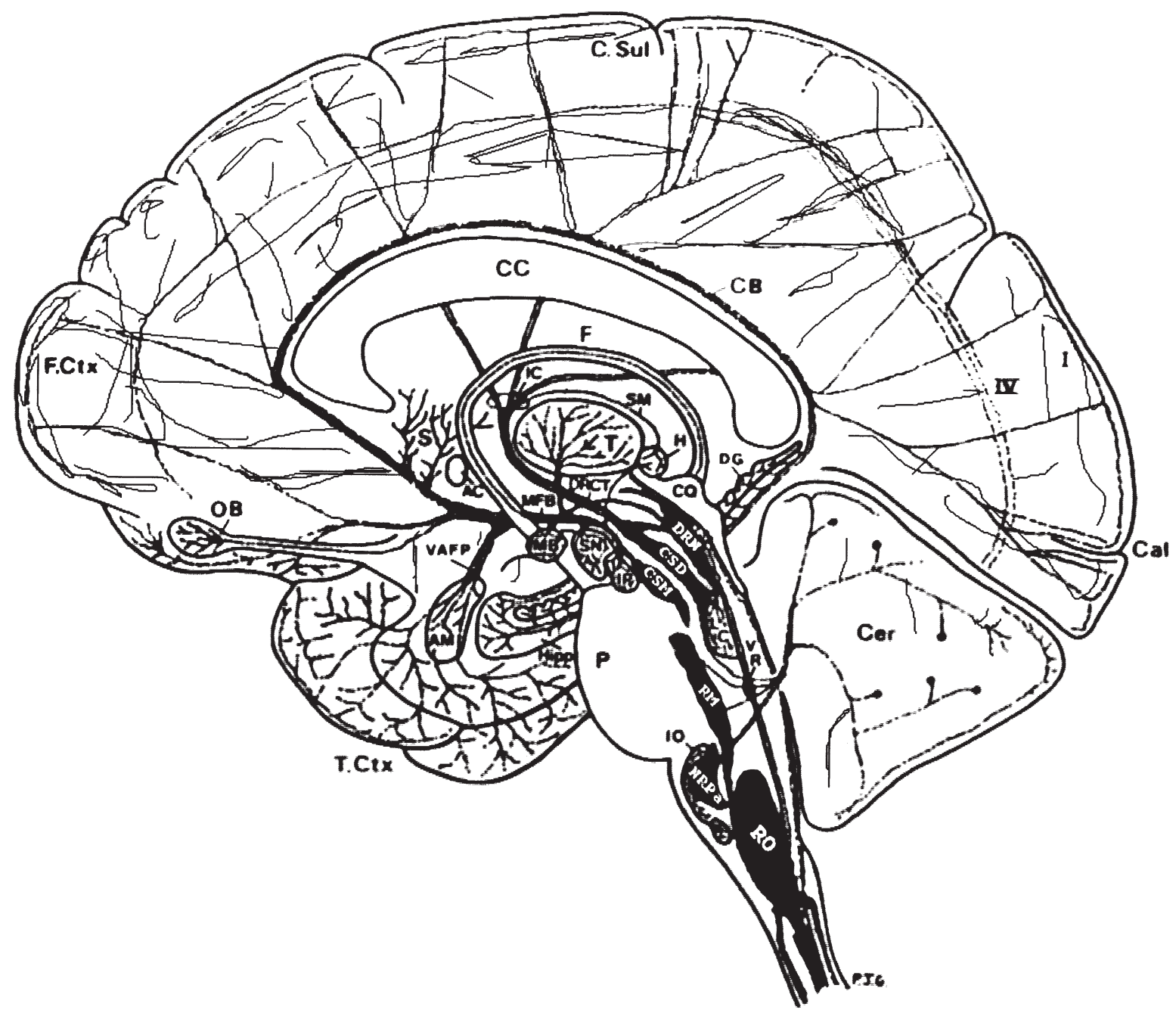

Figure 1. A schematic drawing of the main serotonergic projections in the human brain and spinal cord from the brainstem raphe nuclei. The figure shows the extensive efferents of this set of reticular nuclei. DRM, dosal raphe nucleus; CSD, centralis superior nucleus, pars dorsalis; CSM, centralis superior nucleus, pars medianus; RO, nucleus raphe obscruus; NRPa, nucleus raphe pallidus; RM, nucleus raphe magnus; VR, nucleus raphe ventricularis (modified from Azmitia and Gannon 1986). 
tend from the cervical spinal cord to the interpeduncular nucleus (see Jacobs and Azmitia 1992). The nuclear boundaries of the raphe neurons sometimes conform to classical nuclear designations such as the Nucleus Centralis Superior or Caudal Linear Nucleus (Figure 1). At other times, the cells seems scattered in unconventional locations such as the supralemiscal nucleus designated B9, para-gigantocellularis lateralis, or within the central reticularis region. With respect to development, the neurons form a superior and inferior group of immature cells which have distinct maturational and migrational patterns (Wallace and Lauder 1983; Lidov and Molliver 1982). Even within the superior group, there is evidence the 5-HT neurons form different subsets of cells. The Nucleus Centralis Superior (including the intrafascicular portion of the Dorsal Raphe Nucleus) comes from a different group of neurons than the Linear Caudal Nucleus and the rostral and dorsal part of the Dorsal Raphe Nucleus (see Azmitia and Gannon 1986).

In fluorescence (Dahlstrom and Fuxe 1964) and immunocytochemical (Steinbusch 1981) studies, the cells containing serotonin appear either large or small, having either a multipolar or fusiform shaped perikaryon. The large cells with many spines were first drawn by Cajal (1911) using the Golgi method in Histologie du Systeme Nerveux published in 1911. In electron microscopic studies, the nucleus is seen as being highly invaginated and the cytoplasm has a well-defined Golgi apparatus and abundant microcanuculi (Leger and Descarries 1978; Wiklund et al. 1981; Johnson and Yee 1995) (Figure 2). Both small clear vesicles and dense core vesicles have been described. The major enzymes concentrated in these neurons are tryptophan hydroxylase and aromatic amino-acid decarboxylase, both of which are necessary to synthesize serotonin from tryptophan (Grahame-Smith 1964; Lovenberg et al. 1967). These cells also contain high levels of monoamine oxidase- $\mathrm{B}$, the degradative enzyme having a low affinity for serotonin (Levitt et al. 1982). NADPH diaphorase, necessary for producing nitric oxide, is also found in the large raphe neurons (Rodrigo et al. 1994). Furthermore, the raphe cells have large amounts of the growth associated protein GAP-43, during development and in the adult brain (Curtis et al. 1993; Zou et al. 1996).

The raphe serotonergic neurons contain bioactive neuropeptides. The first neuropeptide reported in a serotonergic cell was substance-P in the Nucleus Raphe Magnus (Chan-Palay 1981; Magoul et al. 1986; Halliday et al. 1988a; Arvidsson et al. 1994). Glutamate, an excitatory neurotransmitter, is also co-localized with serotonin and substance-P in raphe neurons (Nicholas et al. 1992). Other peptides described within the serotonergic neurons are calretinin (Acsady et al. 1993), galanin (Arvidsson et al. 1991), enkephalin (Millhorn et al. 1989; Henry and Manaker 1998), N-acetyl-aspartyl-glutamate (Forloni et al. 1987), neuropeptide-Y (Halliday et al. 1988b; Krukoff et al. 1992), angiotensin II (Krukoff et al. 1992), and thyrotropin releasing hormone (Ulfhake et al. 1987; Sharif et al. 1989; Arvidsson et al. 1994). It has been suggested that serotonin is localized to the small clear vesicles and peptides are concentrated in the dense core vesicles (Pelletier et al. 1977; Johansson et al. 1980, Van Bockstaele and Chan 1997). There is evidence for the co-localization of peptides and serotonin in the dense core vesicles (Pelletier et al. 1981). It would be interesting to know if glutamate exists within both the small and dense core vesicles with serotonin.

The serotonergic neuronal cell bodies have variable sizes (15-60 um diameter), which can be dependent on the hormonal state of the animal. In adrenalectomized animals, lacking circulating adrenal glucocorticoids, the serotonergic neurons in all the raphe groups appear small with thin processes extending from the soma (Azmitia et al. 1993). If dexamethasone is placed in the

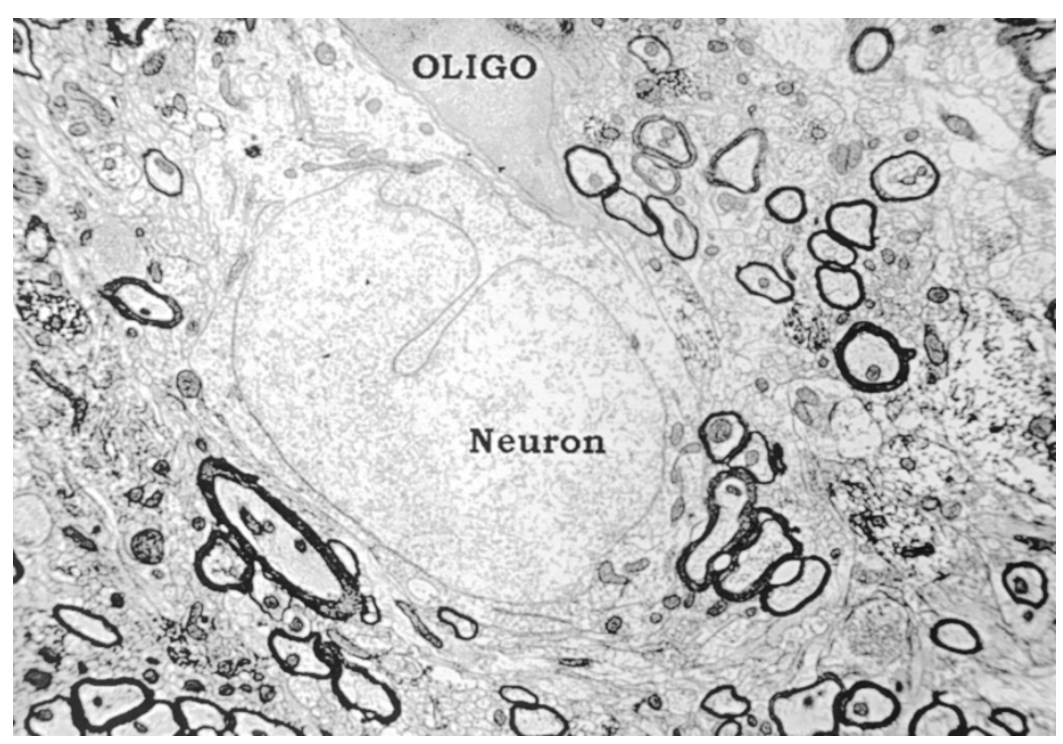

Figure 2. An electron microscopic photograph taken of the Dorsal Raphe Nucleus of the adult rat. The neuron has a well-developed Golgi Apparatus and numerous organelles. The nucleus is indented. A pericellular oligodendroglia has a large area of specialized contact with the neuron. 


\section{DORSAL RAPHE NUCLEUS}
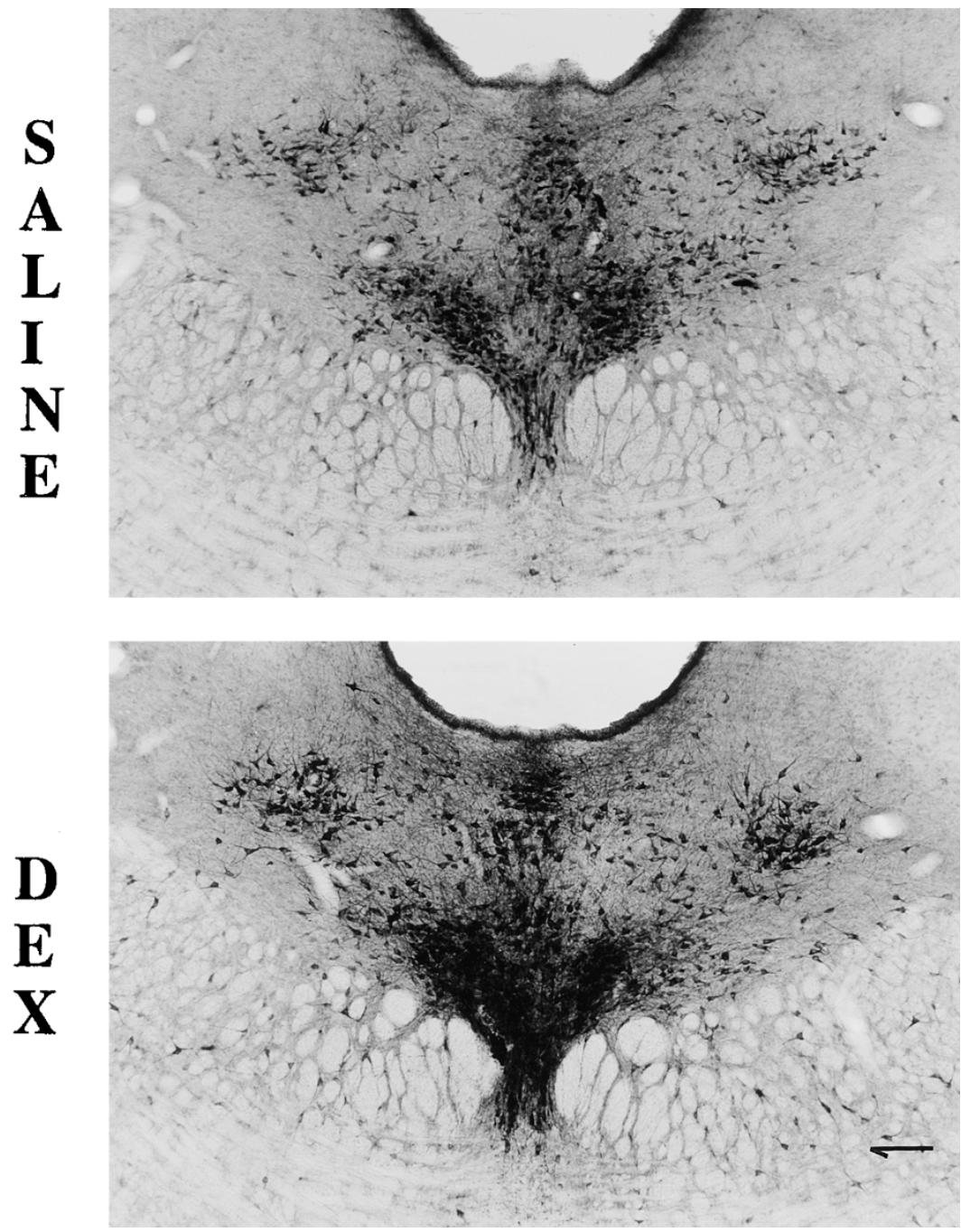

Figure 3. A coronal section of the Dorsal Raphe Nucleus stained with an anti-tryptophan hydroxylase antibody in adrenalectomized (ADX) adult rats. The top photograph is from ADX rat maintained for one week on physiological saline solution alone while the bottom picture is from an ADX rat in which dexamethasone $(1 \mathrm{mg} / \mathrm{l})$ was added to the saline 72 hours before the end of the experiment (reprinted from Azmitia et al. 1993). drinking water, the size of the soma and the processes increases, with an approximately $80 \%$ increase within 24-72 hours in the volume of the tryptophan hydroxylase immunoreactive neurons (Figure 3). The interesting finding was that all serotonergic neurons changed, providing evidence of a common factor linking the plasticity of these neurons. Other hormones and cytokines influencing serotonin include estrogen, testosterone, thyroxine, aldosterone, cholesterol, and interleukins (see Azmitia and Whitaker-Azmitia 1997).

\section{THE SEROTONIN DENDRITES AND AFFERENTS}

The dendrites of the serotonergic neurons receive processes from serotonergic and non-serotonergic axons and dendrites. The identified axonal terminals seen in the raphe nuclei contain serotonin (Dong and Shen
1986); norepinephrine (Baraban and Aghajanian 1981; Takagi et al. 1981; Lee et al. 1987; Dong and Shen 1986); dopamine (Ferre et al. 1994); acetylcholine (Chen et al. 1992; Honda and Semba 1994); GABA (Skinner et al. 1997; Wang et al. 1996), substance-P (Magoul et al. 1986); CLIP/ACTH (Leger et al. 1994); or neurotensin (Uhl et al. 1979) (Figure 3). Many anatomical regions provide connections to the raphe nuclei; and these include inputs from the cortex, hypothalamus, reticular nuclei, brainstem, spinal cord, and habenula (Hermann et al. 1997; Behzadi et al. 1990; Aghajanian and Wang 1977). Serotonergic dendrites extend into the axonal bundles of the medial longitudinal fasciculus, medial lemniscus, trapezoid body, cerebral peduncles, the superior cerebellar peduncles and other fiber bundles which traverse the brainstem carrying both ascending and descending fibers (Azmitia and Segal 1978). The spectrum of inputs from numerous anatomical sources having diverse chemical neurotransmitters and neuropeptides is not 


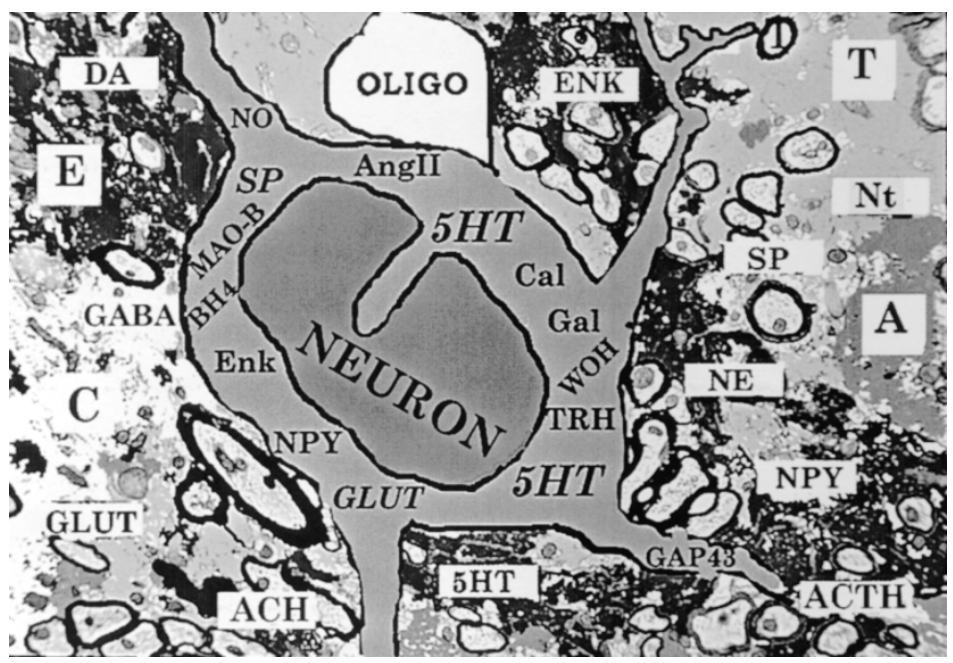

Figure 4. A schematic drawing of a serotonergic neuron next to a pericellular oligodendroglia (OLIGO) with a number of molecules inside and outside the neuron: 5HT, serotonin; A, adrenal steroids; $\mathrm{ACH}$, acetylcholine; ACTH, adrenal corticotrophin hormone; AngII, angiotensin II; BH4, tetra-hydro-biopterin; C, cholesterol; Cal, calretinin; DA, dopamine; E, estrogen; Enk, enkephalin; GABA, gamma-aminobutyric acid; Gal, galanin; GAP-43, growth associated protein; GLUT, glutamate; $\mathrm{MAO}-\mathrm{B}$, monoamine oxidase-B; NE, norepinephrine; NO, Nitric Oxide; $\mathrm{NPY}$, neuropeptide-Y; $\mathrm{Nt}$, neurotensin; $\mathrm{SP}$, substance $\mathrm{P}$; TRH, thyrotropin releasing hormone; $\mathrm{WOH}$, tryptophan hydroxylase. atypical for a large reticular neuron (Figure 4). But given the number of afferents and efferents of this single chemical system, it can transmit the varied signals to both neuronal and non-neuronal targets.

Specialized contacts are seen as axo-dendritic, axosomatic, and dendro-dendritic; however, the majority of the processes are seen as being closely appossed without a specialized contact (Malinsky and Malinska 1992; Kapadia et al. 1985; Chazal and Ralston 1987). In addition, the contacts made between the dendrites may have special significance (Pecci Saavedra et al. 1986; Chazal and Ohara 1986). The serotonergic dendrites contain tryptophan hydroxylase and have the ability to synthesize serotonin from tryptophan. The dendrites contain small clear vesicles that can serve as storage and release sites for serotonin. There is probably no cytoplasmic, non-calcium dependent release from dendrites since there is no evidence for the presence of the 5-HT transporter protein on dendrites (Tao-Cheng and Zhou 1997). Any serotonin released from the dendrites would remain in the neuropil for an extended period of time to interact with dendritic and somatic receptors. Eventually, the released neurotransmitter would be sequested by the numerous 5-HT terminals in the raphe nuclei.

An unusual arrangement in the raphe nuclei, is that the serotonergic soma appear to have extensive contacts with non-neuronal cells (Figure 2). Dendritic bundles from the raphe neurons intertwine with processes from tanocytes coming from the third ventricles (Cummings and Felten 1979). Pericellular oligodendroglia make specialized contacts with the soma of the raphe serotonergic neurons (Azmitia 1978). Contacts with endothelial cells, which surround the blood vessels, are common for both soma and dendrites (Scheibel et al. 1975; Azmitia 1978; Westlund et al. 1993; Gragera et al. 1994). Numerous S100 $\beta$ containing astrocytes flank the developing serotonergic neurons but become somewhat less prominent as the brain matures (Van Hartes- veldt et al. 1986). The special relationship between serotonin and S100 is discussed below when we deal with issues of neuroplasticity. The glial, endocrine, and vascular contacts are consistent with serotonin's special role in integrating electrical, metabolic, and trophic systems within the brain (Figure 4).

\section{THE SEROTONIN AXONS AND EFFERENTS}

Cajal (1911) described the serotonergic neurons as large neurons with extensive but untraceable axonal projections. Using ${ }^{3} \mathrm{H}$-proline as a marker, at least five separate tracts were found ascending from the superior group of raphe nuclei (Azmitia and Segal 1978). Some serotonergic fibers are myelinated (Figure 5), whereas others are unmyelinated, and a variety of fiber diameters can exist within many brain regions (Kohler et al. 1980; Cropper et al. 1984). Some serotonergic neurons form synapses while others engage in non-synaptic interactions (Azmitia 1978; Beaudet and Descarries 1987; Hornung et al. 1990). The serotonergic neurons, present in all brains studied, have evolved numerous morphological characteristics within the CNS of vertebrates, properties that at times appear incompatible for accomplishing a unified role.

Some researchers have attempted to classify serotonergic neurons into two distinct categories principally based on fiber type. One fiber type, which is thick, relatively straight and non-varicose, is said to originate in the Median Raphe Nucleus and the other, which is thin, highly branched and varicose, from the Dorsal Raphe Nucleus (Hornung et al. 1990; Kosofsky and Molliver 1987). This rigid distinction is not universally accepted since it appears the morphology of the fibers may depend on the target region innervated (see Azmitia 1978) and appear to fluctuate during development or after injury. In fact, serotonergic fibers innervate the lateral 


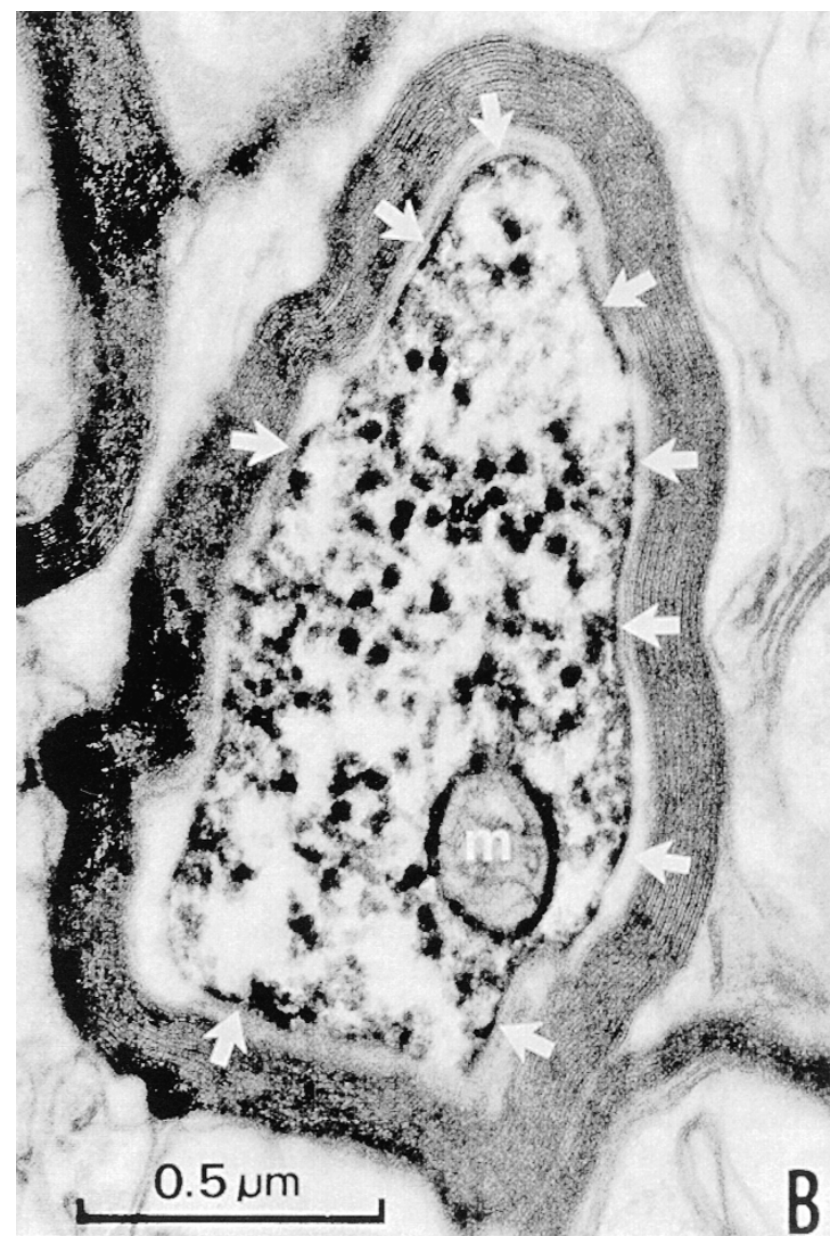

Figure 5. An electron microscopic photograph taken of a myelinated axon immunocytochemically stained with an anti-5-HT antibody in an adult monkey brain in the medial forebrain bundle. Note the location of immunoreactivity in the small synaptic vesicles (reprinted from Azmitia and Gannon 1983).

ventricles from fibers that traveled in the medial forebrain bundle before entering the ventricles anteriorly at the level of the septum (Dinopoulos and Dori 1995). These fibers are initially thick, straight, and non-varicose at 1 week postnatal in the rat. However, these same fibers become thin, highly branched, and varicose by the third week of life. Thus, the appearance of the fiber may reflect their development stage and that of their target cells, rather than being a defining static characteristic of the parent neuron itself.

The innervation of the ependymal cells within the ventricle is only one type of non-neuronal projection, which the raphe neurons show. The fibers flood the entire ventral floor of the fetal brain and project into various target areas in the forebrain and spinal cord. The fibers grow along blood vessels and established fiber connections such as the fornix, fasciculus retroflexus, lemniscal pathways, medial longitudinal fasciculus, and pyramidal tracts (Azmitia and Segal 1978). Serotonergic fibers reach the sympathetic preganglion neurons (Bacon et al. 1990), the sensory glomeruli in the olfactory bulb, the intermediate lobe of the pituitary gland (Mezey et al. 1984), the endothelial cells of the choroid plexus (Napoleone et al. 1982), the lateral ventricles (Aghajanian and Gallager 1975; Lorez and Richards 1982), the motoneurons of brainstem (Connaughton et al. 1986), the spinal cord (Alvarez et al. 1998,) and nearly every region of the cerebral cortex (Molliver 1987). In these diverse targets, specialized contacts are common on motoneurons: the dopaminergic neurons in the substania nigra (Moukhles et al. 1997; Van Bockstaele et al. 1994; Herve et al. 1987) and the noradrenergic neurons in locus coeruleus (Pickel et al. 1978; Leger and Descarries 1978; Segal 1979); on the pace-maker neurons of the suprachiasmatic nucleus (Guy et al. 1987; Moga and Moore 1997); and on specialized calbindin GABAergic interneurons in the hippocampus (Hornung and Celio 1992; Freund 1992). In addition, close appositions are seen thoughout the brain on glial cells, pineal gland (Moller 1976), subcommisural organ (Mollgard and Wiklund 1979; Marcinkiewicz and Bouchaud 1986; Voutsinos et al. 1994), endothelial cells (Kobayashi et al. 1985, Azmitia 1978), and ependymal cells (Aghajanian and Gallager 1975; Lorez and Richards 1982). If the concept of volume transmission is accepted, we may say, with out too much effort, that every cell in the brain is exposed to serotonin.

An important insight to consider is that the flow of serotonin from the brainstem serotonergic neurons is not only anterograde, but also retrograde from the forebrain. Injection of ${ }^{3} \mathrm{H}-5-\mathrm{HT}$ is rapidly transported back into the raphe soma from the olfactory bulb (Araneda et al. 1980) and from the hippocampus (Azmitia 1981). The retrograde flow is as robust as the traditional movement of proteins such as horseradish peroxidase and signifies that the role of serotonin synthesis is not only for release at the terminal, but also for intracellular utilization within the perikaryon. Thus serotonin can act as a bi-directional cue from serotonergic terminals to either the target cells by release or to the brainstem raphe nuclei by retrograde transport.

\section{NEUROPLASTICITY OF SEROTONERGIC NEURONS AND IMPACT ON TARGET CELL MATURATION}

The extensive innervation pattern is complemented by the precocious growth shown by these fibers in the immature brain. In fact, in drosophila, the serotonergic innervation can be viewed as a consequence of segmentation of the brainstem under the control of the early expressing HOX genes (Hunter and Kenyon 1995). This role of serotonergic neurons as an early organizer sug- 


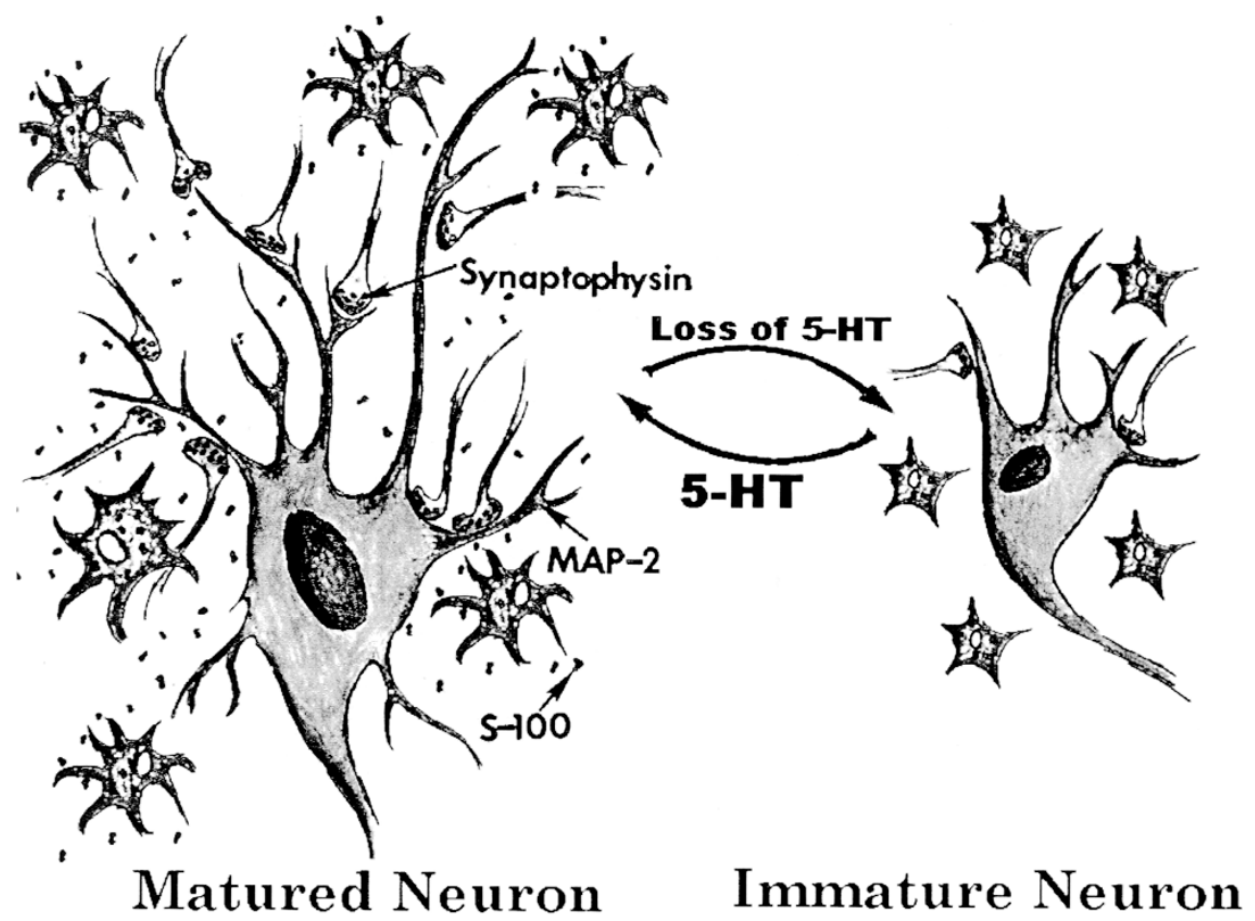

Figure 6. A schematic picture shows the dynamic changes (curved arrows) in neuronal morphology in the presence or absence of serotonin (5-HT). $\mathrm{S} 100 \beta$ is a glial-derived calcium binding protein, which had been shown to promote cytoskeleton assembly. S100 $\beta$ is released from astrocytes (see arrow marked with label S100ß) by the action of 5-HT1A receptor agonist. In the presence of high $\mathrm{Ca}^{++} \mathrm{S} 100 \beta$ forms a dimer called S100B. MAP-2 is a microtubule-associated protein which helps to stabilize the cytoskeleton in dendrites. Synaptophysin is a protein found associated with the vesicles in axons (see arrow with label).

gests it serve to influence overall brain patterning. In addition, serotonin is trophic on its target cells in lobsters (Benton et al. 1997). In the brains of mammals, the serotonergic fibers are among the first fibers to innervate the forebrain and spinal cord from the brainstem (Lidov and Molliver 1982; Wallace and Lauder 1983). The serotonergic fibers innervate cerebral cortex by day 17 of gestation in the rat, just before the cerebral cortex begins to develop a laminar structure (Wallace and Lauder 1983). Studies have shown that delaying the ingrowth of serotonergic fibers, produced significant delays in neuronal maturation as evidenced by delayed final mitosis (Lauder and Krebs 1978), dendritic elongation and spine appearance (Yan et al. 1997), barrel field formation (Blue et al. 1991), and synaptogenesis (Mazer et al. 1997; Wilson et al. 1998). Similar results are seen in the mature brain (Cheng et al. 1994; Azmitia et al. 1995; Whitaker-Azmitia et al. 1995). Tissue culture studies of glial cells indicate that $5 \mathrm{HT}$ is a differentiating factor on non-neuronal target cells as well (Whitaker-Azmitia et al. 1990). Thus, serotonin can be considered a differentiating factor to its target cells within the brain, in both vertebrates and invertebrates.

Serotonergic fibers are very plastic in the mature brain. Damage to the long fibers projecting into the spinal cord or to the forebrain induces a vigorous regenerative sprouting response. In the spinal cord, the new regenerating fibers can establish contacts with motoneurons and restore normal spinal reflexes disrupted after the lesion (Nobin et al. 1973). In the forebrain, a similar dynamic response is found after lesioning of serotonergic fibers in the hypothalamus, which leads to loss of 5-HT, and hypersexuality (Frankfurt et al. 1985). Within a few days, new sprouts form on the damaged 5-HT axons and normal density is measured after about 4-5 weeks. The regenerative sprouts are able to correct the hypersensitive response to sexual hormones. The sprouting of serotonergic neurons can also come from undamaged serotonergic neurons when neighboring 5-HT fibers are removed (Azmitia et al. 1978). This homotypic collateral sprouting response can be maintained for over a year and results in both morphological and functional restoration. The signal for sprouting response is loss of serotonin and the mechanism appears to involve glial trophic factor S100 (Azmitia et al. 1990).

In the adult brain, removal of serotonin results in loss of synapses (Cheng et al. 1994; Wilson et al. 1998) reduction in the expression of synaptophysin and MAP-2 (markers for synapses and dendrites, respectively) (Azmitia et al. 1995; Whitaker-Azmitia et al. 1995), and decreased levels of S-100 $\beta$ (Azmitia et al. 1992; Haring et al. 1993). All these events are indicative of a return to an immature, undifferentiated brain stage. (See Figure 6.) This crucial role for serotonin is probably accomplished by its regulation of the soluble, calcium binding protein, S100 $\beta$, from astrocytes (WhitakerAzmitia et al. 1990). The gene for $S 100 \beta$ is within the obligatory region for Down's syndrome on chromosome 21 (Allore et al. 1988). S100ß, within neurons, functions to stabilize the microtubules and permit the elaborate branching pattern seen within the mature neurons in the brain (Nishi et al. 1996). In S100 $\beta$ transgenic mice, the neurons in the hippocampus develop 
dendritic branches at an accelerated rate (WhitakerAzmitia et al. 1997). However, the increased rate of dendritic branching seen in the $S 100 \beta$ transgenic mice may be a model for Down syndrome, since by six months the dendrites appear to be damaged and reduced in number. This is reminiscent of the usual development of Alzheimer disease by the Down patients in mid-life (Godridge et al. 1987).

The functional consequences of removing 5-HT impacts upon nearly every behavioral and biological process studied. A sampling of these functions includes, but is not limited to aggression, learning, sexual behavior, pain, attention, temperature, appetite, steroid secretion, respiratory rate, sleep, and blood flow. Psychiatric and neurological disorders associated with altered brain serotonin activity include depression, schizophrenia, Down syndrome, Alzheimer disease, autism, attention deficit disorder, alcoholism, and sleep apnea (see Figure 7) This broad spectrum of functional changes is compatible with the wide distribution of the 5-HT fibers, but is intriguing because they appear to be associated with changes in 5-HT innervation. (Arango et al. 1997; Storga et al. 1996; Owens and Nemeroff 1994). The evidence for structural changes in the 5-HT system would provide an explanation for the lag-times for many serotonergic drugs to become effective in treating depression and schizophrenia (see Chapters by Mann (1999), Blier and de Montigny (1999), and Meltzer (1999). The serotonin involvement in functional and clinical disorders is even more compelling when the trophic effects of 5-HT on its targets cells is considered. When serotonergic fibers are removed from an area of the brain, both the structure and function of that region are compromised. Thus, the loss of serotonin in the mature brain could compromise the adaptability and stability of the neural tissue (e.g., neurons, glial, vascular) to dynamically and effectively respond to stimuli from the external environment. The result in loss of serotonin's role in neural tissue homeostasis would be mental illness.

\section{SEROTONIN NEUROPLASTICITY: A KEY VARIABLE IN HOMEOSTASIS AND EVOLUTION}

The multiple roles of serotonin throughout the life of the brain (development and aging) are as puzzling as the roles shown by serotonin throughout evolution. Attempts to provide a unified function for serotonin are elusive since the literature on this one chemical system is filled with apparent contradictions and enigmas. Serotonin, as a neurotransmitter, produces rapid postsynaptic effects at defined synapses, but as a trophic factor, it regulates the maturation of its target cells directly and by causing release of glial $S 100 \beta$. The complexity of function is matched by the complexity of anatomy. The raphe serotonergic neurons, which are located in the brainstem reticular formation, have extensive interactions with classical and peptidergic neurons throughout the neuroaxis, but they also have specialized contacts with endothelial, ependymal, endocrine, astrocytes, and oligodendroglial cells. These varied contacts with many different cell types gives this single chemical system an opportunity to influence all neural tissue, rather than selected neuronal circuits. Even the morphology of the serotonergic neurons itself is varied, and consistent with multiple functions. For example, the fibers, which extend from the serotonergic neurons, can be heavily myelinated to ensure rapid transmission of an electrical signal to a distant target. In the same pathway, other serotonergic fibers are unmyelinated and extensively branched, which provides a means for effective volume transmission of a trophic factor along the entire length of the fiber. Therefore, serotonergic neurons have a structural organization, which is compatible with its functions as both neurotransmitter and trophic factor, and indicates its role is more complex than can be explained by considering its effects on neuropsychopharmacology alone.

A critical question becomes what turns on this complex system? It has already been pointed out that con-

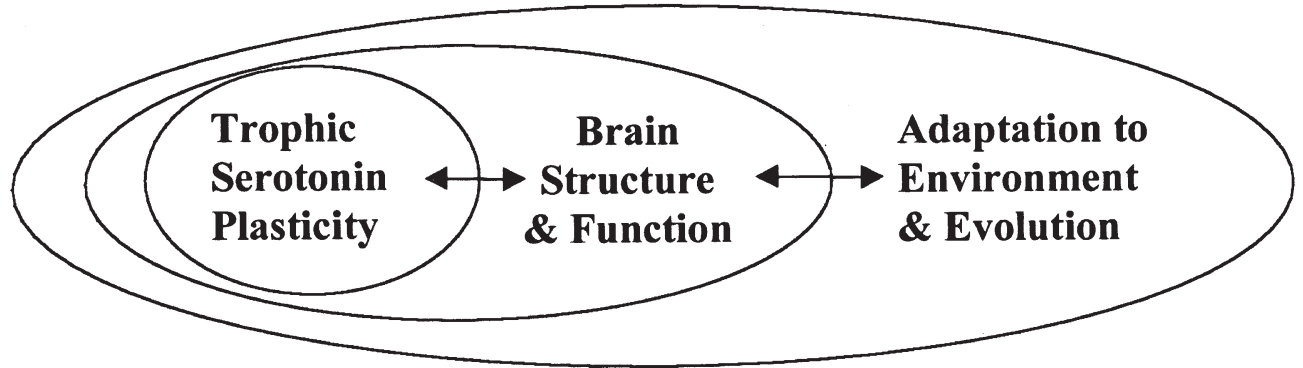

Figure 7. A schematic drawing of three interacting sphere of interaction showing how external factors act on various systems within the body to impinge on serotonergic neuronal plasticity. The inner sphere comprises brain homeostasis where the plasticity of 5-HT neurons trophic influences target-cell neuronal morphology. The structure of the brain is the basis of all neuronal networks and, thus function. In the outer sphere, the interactions between the environment and the brain are shown. An inability to properly adapt to the environment would have direct implications on evolution. Our model predicts serotonin dysfunction results in maladjustment of the organism to the environment because of deficits in brain morphology. 
nections between serotonergic neurons and a variety of cells exist. Most of the attention is given to the effects of neurotransmitters on the serotonergic neurons but these raphe neurons also contact blood vessels and respond not only to changes in blood pressures, but also to a variety of substances carried in the blood. These would include oxygen, glucose, amino-acids, steroids, carbohydrates, and toxins. Normally these chemicals are used to maintain the levels of serotonin but peripheral infections can drastically change serotonin levels and related functions (Freund et al. 1986). Besides these blood-related compounds, serotonin neurons are directly exposed to CSF. As mentioned above, serotonergic fibers appear to travel from brain tissue into the ventricles, indicating the same neuron integrates neuronal and CSF factors. This is an important point, because it implies serotonin's role as neurotransmitter is shaped by its non-neuronal interactions.

In this paper, I have proposed a structural and functional organization for serotonin to interact with a large number of cells within the brain by mechanisms influenced locally (e.g., synapses) or globally (e.g., vascular). However, a central issue in proposing a homeostatic role for serotonin involves feedback regulation. Serotonin responds to many neuropeptides, chemicals and steroids, and, in turn, influences the production and release of these same agents. For example, glucocorticoids increase the size of serotonergic neurons, its synthesis and release, as well as the levels of its postsynaptic receptors. In turn, serotonin, acting through a variety of receptor subtypes, regulates the release of CRF from the hypotalamus, which releases ACTH from the pituitary and ultimately cortisol from the adrenal, a feedback process involving brain, pituitary, vascular, and endocrine systems. These complex systems do not develop only in the brain or appear suddenly in mammals. These interactions evolve slowly and from the earliest known biological systems. Serotonin has important functions in plant root development and in invertebrate adaptive behaviors. Serotonergic neurons, present in the brain from the beginning of neural evolution, have established diverse and complex cellular phenotypes and neural interactions within the dynamic architecture of the brain. I propose that the serotonin system in the brain, and its plastic properties, are central to the ability of the brain to integrate with the peripheral organs of the body and with the outside environment as well (Figure 7). Changes in the functioning of serotonergic neurons, due to more effective transporter proteins or more sensitive receptors, all impact on the ability of the brain and the organism, to adapt and succeed in nature. Maladaption of the serotonin system in neural homeostasis is expected to be as harmful to mental functioning as disruption of the General Adaptive Syndrome in stress is harmful to normal health (Selye 1956). An aggressive, violent, hypersexual paranoid individual is not compatible with the social and psychiatric norms today; but the tendency to display these abnormal disorders maybe rooted in the evolutionary history of serotonin. Effective treatment of these disorders may require more consideration to trophic and plastic properties than currently shown.

\section{ACKNOWLEDGMENTS}

Current funding obtained from the National Institute of Mental Health Grant NIMH-NIH-55250.

\section{REFERENCES}

Acsady L, Halasy K, Freund TF (1993): Calretinin is present in non-pyramidal cells of the rat hippocampus-III. Their inputs from the median raphe and medial septal nuclei. Neuroscience 52:829-841

Aghajanian GK, Gallager DW (1975): Raphe origin of serotonergic nerves terminating in the cerebral ventricles. Brain Res 88(2):221-231

Aghajanian GK, Wang RY (1977): Habenular and other midbrain raphe afferents demonstrated by a modified retrograde tracing technique. Brain Res 122:229-242

Allore R, O'Hanlon D, Price R, Neilson K, Willard HF, Cox DR, Marks A, Dunn RJ (1988): Gene encoding the beta subunit of S100 protein is on chromosome 21: Implications for Down syndrome. Science 239(4845):1311-1313

Alvarez FJ, Pearson JC, Harrington D, Dewey D, Torbeck L, Fyffe RE (1998): Distribution of 5-hydroxytryptamineimmunoreactive boutons on alpha-motoneurons in the lumbar spinal cord of adult cats. J Comp Neurol 393:69-83

Araneda S, Gamrani H, Font C, Calas A, Pujol JF, Bobillier P (1980): Retrograde axonal transport following injection of $[3 \mathrm{H}]$-serotonin into the olfactory bulb. II. Radioautographic study. Brain Res 196:417-427

Arango V, Underwood MD, Mann JJ (1997): Postmortem findings in suicide victims. Implications for in vivo imaging studies. Ann N Y Acad Sci 836:269-287

Arvidsson U, Cullheim S, Ulfhake B, Luppi PH, Kitahama K, Jouvet M, Hokfelt T (1994): Quantitative and qualitative aspects on the distribution of 5-HT and its coexistence with substance $\mathrm{P}$ and TRH in cat ventral medullary neurons. T J Chem Neuroanat 7:3-12

Arvidsson U, Ulfhake B, Cullheim S, Bergstrand A, Theodorson E, Hokfelt T (1991): Distribution of ${ }^{125}$ I-galanin binding sites, immunoreactive galanin, and its coexistence with 5-hydroxytryptamine in the cat spinal cord: biochemical histochemical and experimental studies at the light and electron microscopic level. J Comp Neurol 308:115-138

Azmitia EC (1978): The serotonin-producing neurons of the midbrain median and dorsal raphe nuclei. In Iversen LL, Iversen SD, Snyder SH (eds), Handbook of Psychoparmacology, vol. 9. New York, Plenum Press, pp 233314

Azmitia EC (1981): Bilateral serotonergic projections to the 
dorsal hippocampus of the rat: Simultaneous localization of ${ }^{3} \mathrm{H}-5 \mathrm{HT}$ and HRP after retrograde transport. J Comp Neurol 203:737-774

Azmitia EC, Buchan AM, Williams JH (1978): Structural and functional restoration by collateral sprouting of hippocampal 5-HT axons. Nature 274:374-377

Azmitia EC, Dolan K, Whitaker-Azmitia PM (1990): S-100 but not NGF, EGF, insulin or calmodulin functions as a CNS serotonergic growth factor. Brain Res 516:354-356

Azmitia EC, Gannon PJ (1986): Anatomy of the serotonergic system in the primate and sub-primate brain. Adv Neurol 43:407-468

Azmitia EC, Gannon PJ (1983): The ultrastructural localization of serotonin immunoreactivity in myelinated and unmyelinated axons within the medial forebrain bundle of rat and monkey. J Neurosci 3:2083-2090

Azmitia EC, Griffin SW, Marshak DR, VanEldik LT, Whitaker-Azmitia PM (1992): 5- $\mathrm{HT}_{1 \mathrm{~A}}$ and S-100 $\beta$; a neurona/glial link to Alzheimers Disease. Prog Brain Res 94: 459-473

Azmitia EC, Segal M (1978): An autoradiographic analysis of the differential ascending projections of the dorsal and median raphe nuclei in the rat. J Comp Neurol 179:641659

Azmitia EC, Liao B, Chen Y (1993): Increase of tryptophan hydroxylase enzyme protein by dexamethasone in adrenalectomized rat midbrain. J Neurosci 13:5041-5055

Azmitia EC, Rubinstein VJ, Strafaci JA, Rios JC, WhitakerAzmitia PM (1995): 5- $\mathrm{HT}_{1 \mathrm{~A}}$ agonist and dexamethasone reversal of para-chloroamphetamine induced loss of MAP-2 and synaptophysin immunoreactivity in adult rat brain. Mol Brain Res 677:181-192

Azmitia EC, Whitaker-Azmitia PM (1997): Handbook of experimental pharmacology: Serotonergic neurons and 5 -HT receptors in the CNS. In Baumgarten HG, Gothert M (eds), Development and Neuroplasticity of Central Serotonergic Neurons, pp 1-39

Bacon SJ, Zagon A, Smith AD (1990): Electron microscopic evidence of a monosynaptic pathway between cells in the caudal raphe nuclei and sympathetic preganglionic neurons in the rat spinal cord. Exp Brain Res 79:589-602

Baraban JM, Aghajanian GK (1981): Noradrenergic innervation of serotonergic neurons in the dorsal raphe: Demonstration by electron microscopic autoradiography. Brain Res 204(1):1-11

Beaudet A, Descarries L (1987): Ultrastructural identification of serotonin neurons. In Steinbusch HWM (ed), Monoaminergic Neurons: Light Microscopy and Ultrastructure. New York, NY, John Wiley \& Sons, pp 265-313

Behzadi G, Kalen P, Parvopassu F, Wiklund L (1990): Afferents to the median raphe nucleus of the rat: Retrograde cholera toxin and wheat germ conjugated horseradish peroxidase tracing, and selective D-[3H]aspartate labelling of possible excitatory amino acid inputs. Neuroscience 37(1):77-100

Benton J, Huber R, Ruchhoeft M, Helluy S, Beltz B (1997): Serotonin depletion by 5,7-dihydroxytryptamine alters deutocerebral development in the lobster, Homarus americanus. J Neurobiol 33:357-373

Blier P, de Montigny C (1999): Serotonin and drug-induced therapeutic responses in major depression obsessive- compulsive and panic disorders. Neuropsychopharmacology 21(2S):91S-98S

Blue ME, Erzurumlu RS, Jhaveri S (1991): A comparison of pattern formation by thalamocortical and serotonergic afferents in the rat barrel field cortex. Cereb Cortex $1: 380-389$

Brodie BB, Shore PA (1957): Ann NY Acad Sci 66:631

Cajal RYS (1911): Histologie du Systeme Nerveux de l'Homme et des Vertebres II. Paris: A. Malone

Cannon WB (1929): Organization for physiological homeostasis. Physiol Rev 9:399-431

Chan-Palay V (1981): Evidence for the coexistence of serotonin and substance $P$ in single raphe cells and fiber plexuses: Combined immunocytochemistry and autoradiography. Adv Exp Med Biol 133:81-97

Chazal G, Ohara PT (1986): Vesicle-containing dendrites in the nucleus raphe dorsalis of the cat. A serial section electron microscopic analysis. J Neurocytol 15:777-787

Chazal G, Ralston 3d HJ (1987): Serotonin-containing structures in the nucleus raphe dorsalis of the cat: An ultrastructural analysis of dendrites, presynaptic dendrites, and axon terminals. J Comp Neurol 259:317-329

Chen HY, Lin YP, Lee EH (1992): Cholinergic and GABAergic mediations of the effects of apomorphine on serotonin neurons. Synapse 10(1):34-43

Cheng L, Hamaguchi K, Ogawa M, Hamada S, Okada N (1994): PCPA reduces both monoaminergic afferents and nonmonoaminergic synapses in the cerebral cortex. Neurosci Res 19:111-115

Connaughton M, Priestley JV, Sofroniew MV, Eckenstein F, Cuello AC (1986): Inputs to motoneurones in the hypoglossal nucleus of the rat: Light and electron microscopic immunocytochemistry for choline acetyltransferase, substance $\mathrm{P}$ and enkephalins using monoclonal antibodies. Neuroscience 17:205-224

Cropper EC, Eisenman JS, Azmitia EC (1984): 5-HT- immunoreactive fibers in the trigeminal nuclear complex of the rat. Exp Brain Res 55:515-522

Cummings JP, Felten DL (1979): A raphe dendrite bundle in the rabbit medulla. J Comp Neurol 183:1-23

Curtis R, Averill S, Priestley JV, Wilkin GP (1993): The distribution of GAP-43 in normal rat spinal cord. J Neurocytol 22:39-50

Dahlstrom A, Fuxe K (1964): Evidence for the existence of monoamine- containing neurons in the central nervous system: I. Demonstration of monoamines in the cell bodies of brainstem neurons. Acta Physiol Scand 62(Suppl 232):1-55

Dinopoulos A, Dori I (1995): The development of the serotonergic fiber network of the lateral ventricles of the rat brain: A light and electron microscopic immunocytochemical analysis. Exp Neurol 133:73-84

Dong XW, Shen E (1986): Origin of monoaminergic innervation of the nucleus raphe magnus - a combined monoamine histochemistry and fluorescent retrograde tracing study in the rat. Sci Sin [B] 29(6):599-608

Ferre S, Cortes R, Artigas F (1994): Dopaminergic regulation of the serotonergic raphe-striatal pathway: Microdialysis studies in freely moving rats. J Neurosci 14(8):4839-4846 
Fischer H (1971):Vergleichende Pharmakologie von Ubertragersubstanzen in tiersystematischer Darstellung. Berlin, Heidelberg, New York, Springer Verlag

Forloni G, Grzanna R, Blakely RD, Coyle JT (1987): Co-localization of N-acetyl-aspartyl-glutamate in central cholinergic, noradrenergic, and serotonergic neurons. Synapse 1(5):455-460

Frankfurt M, Renner KJ, Azmitia EC, Luine V (1985): Intrahypothalamic 5,7- dihydroxytryptamine: Temporal analysis of effects on 5-HT content in brain nuclei and on facilitated lordosis behavior. Brain Res 340:127-133

Freund TF (1992): GABAergic septal and serotonergic median raphe afferents preferentially innervate inhibitory interneurons in the hippocampus and dentate gyrus. Epilepsy Res Suppl 7:79-91

Freund HR, Muggia-Sullam M, LaFrance R, Holroyde J, Fischer JE (1986): Regional brain amino acid and neurotransmitter derangements during abdominal sepsis and septic encephalopathy in the rat. The effect of amino acid infusions. Arch Surg Feb; 121:209-216

Garattini S, Valzelli L (1965): Serotonin. Amsterdam, The Netherlands, Elsevier

Gershon MD (1991): Serotonin: its role and receptors in enteric neurotransmission. Adv Exp Med Biol 294:221230

Godridge H, Reynolds GP, Czudek C, Calcutt NA, Benton M (1987): Alzheimer-like neurotransmitter deficits in adult Down's syndrome brain tissue. J Neurol Neurosurg Psychiatry 50(6):775-778

Gragera RR, Muniz E, Martinez-Rodgriguez R (1994):Neuromediators in the cerebellar blood-brain barrier and its microenvironment. Immunocytochemical demonstration of taurine, glycine, serotonin, thiamin and AATase. J Hirnforsch 35(1):31-38

Grahame-Smith DG (1964): Tryptophan hydroxylation in brain. Biochem Biophys Res Commun 16:586-592

Guy J, Bosler O, Dusticier G, Pelletier G, Calas A (1987): Morphological correlates of serotonin-neuropeptide $Y$ interactions in the rat suprachiasmatic nucleus: Combined radioautographic and immunocytochemical data. Cell Tissue Res 250(3):657-662

Halliday GM, Li YW, Joh TH, Cotton RG, Howe PR, Geffen LB, Blessing WW (1988a): Distribution of substance P-like immunoreactive neurons in the human medulla oblongata: Co-localization with monoamine-synthesizing neurons. Synapse 2(4):353-370

Halliday GM, Li YW, Oliver JR, Joh TH, Cotton RG, Howe PR, Geffen LB, Blessing WW (1988b): The distribution of neuropeptide Y-like immunoreactive neurons in the human medulla oblongata. Neuroscience 26(1):179-191

Haring JH, Hagan A, Olson J, Rodgers B (1993): Hippocampal serotonin levels influence the expression of S100 beta detected by immunocytochemistry. Brain Res 631:119-123

Henry JN, Manaker S (1998): Colocalization of substance P or enkephalin in serotonergic neuronal afferents to the hypoglossal nucleus in the rat. J Comp Neurol 391(4): 491-505

Hermann DM, Luppi PH, Peyron C, Hinckel P, Jouvet M (1997): Afferent projections to the rat nuclei raphe magnus, raphe pallidus and reticularis gigantocellularis pars alpha demonstrated by iontophoretic application of choleratoxin (subunit b ). J Chem Neuroanat 13(1):1-21

Herve D, Pickel VM, Joh TH, Beaudet A (1987): Serotonin axon terminals in the ventral tegmental area of the rat: fine structure and synaptic input to dopaminergic neurons. Brain Res 435:71-83

Hess WR (1954): "Das Zwischenhirn." Basel: Benno Schwabe

Honda T, Semba K (1994): Serotonergic synaptic input to cholinergic neurons in the rat mesopontine tegmentum. Brain Res 647:299-306

Hornung JP, Celio MR (1992):The selective innervation by serotoninergic axons of calbindin-containing interneurons in the neocortex and hippocampus of the marmoset. J Comp Neurol 320(4):457-467

Hornung J-P, Fritschy J-M, Tork I (1990): Distribution of two morphologically distinct subsets of serotonergic axos in the cerebral cortex of the marmoset. J Comp Neurol 297:165-181

Hunter CP, Kenyon C (1995): Specification of anteroposterior cell fates in Caenorhabditis elegans by Drosophila Hox proteins. Nature 377:229-232

Jacobs BL, Azmitia EC (1992): Structure and function of the brain serotonin system. Physiol Rev 72:165-229

Johansson O, Hokfelt T, Jeffcoate SL, White N, Sternberger LA (1980): Exp Ultrastructural localization of TRH-like immunoreactivity. Brain Res 38(1):1-10

Johnson MD, Yee AG (1995): Ultrastructure of electrophysiologically-characterized synapses formed by serotonergic raphe neurons in culture. Neuroscience 67:609-623

Kapadia SE, de Lanerolle NC, LaMotte CC (1985): Immunocytochemical and electron microscopic study of serotonin neuronal organization in the dorsal raphe nucleus of the monkey. Neuroscience 15:729-746

Kobayashi H, Magnoni MS, Govoni S, Izumi F, Wada A, Trabucchi M (1985): Neuronal control of brain microvessel function. Experientia 41(4):427-434

Kohler C, Chan-Palay V, Haglund L, Steinbusch HWM (1980): Immunohistochemical localization of serotonin nerve terminals in the lateral entorhinal cortex of the rat: Demonstration of two separate patterns of innervation from the midbrain raphe. Anat Embryol (Berl) 160:121-129

Kosofsky BE, Molliver ME (1987): The serotonergic innervation of cerebral cortex: Different classes of axon terminals arise from dorsal and median raphe nuclei. Synapse 1:153-168

Krukoff TL, Vu T, Harris KH, Aippersbach S, Jhamandas JH (1992): Neurons in the rat medulla oblongata containing neuropeptide $\mathrm{Y}-$, angiotensin II-, or galanin-like immunoreactivity project to the parabrachial nucleus. Neuroscience 7:175-184

Lauder JM, Krebs H (1978): Serotonin as a differentiation signal in early neurogenesis. Develop Neurosci 1:15-30

Lee EH, Wang FB, Tang YP, Geyer MA (1987): Gabaergic interneurons in the dorsal raphe mediate the effects of apomorphine on serotonergic system. Brain Res 18(3): 345-353

Leger L, Bonnet C, Cespuglio R, Jouvet M (1994): Immunocytochemical study of the CLIP/ACTH-immunoreac- 
tive nerve fibres in the dorsal raphe nucleus of the rat Neurosci Lett 174:137-140

Leger L, Descarries L (1978): Serotonin nerve terminals in the locus coeruleus of adult rat: A radioautographic study. Brain Res 145(1):1-13

Levitt P, Pintar JE, Breakefield XO (1982): Immunocytochemical demonstration of monoamine oxidase $B$ in brain astrocytes and serotonergic neurons. Proc Natl Acad Sci USA 79:6385-6389

Lidov HGW, Molliver ME (1982): An immunohistochemical study of serotonin neuron development in the rat: ascending pathways and terminal fields. Brain Res Bull 8:389-430

Lorez HP, Richards JG (1982): Supra-ependymal serotoninergic nerves in mammalian brain: Morphological pharmacological and functional studies. Brain Res Bull 9:727-741

Lovenberg W, Jequier E, Sjoerdsma A (1967): Tryptophan hydroxylation: measurement in pineal gland, brainstem, and carcinoid tumor. Science 155:217-219

Magoul R, Onteniente B, Oblin A, Calas A (1986): Inter- and intracellular relationship of substance P-containing neurons with serotonin and GABA in the dorsal raphe nucleus: Combination of autoradiographic and immunocytochemical techniques. J Histochem Cytochem 34:735-742

Malinsky J, Malinska J (1992): The nucleus raphe magnus of the cat. II. Quantitative analysis of axosomatic synapses. Acta Univ Palacki Olomuc Fac Med 134:17-21

Mann JJ (1999): Role of serotonergic system in the pathogenesis of major depression and suicidal behavior. Neuropsychopharmacology 21(2S):99S-105S

Marcinkiewicz M, Bouchaud C (1986): Formation and maturation of axo-glandular synapses and concomitant changes in the target cells of the rat subcommissural organ. Biol Cell 56(1):57-65

Mazer C, Muneyyirci J, Taheny K, Raio N, Borella A, Whitaker-Azmitia P (1997): Serotonin depletion during synaptogenesis leads to decreased synaptic density and learning deficits in the adult rat: A possible model of neurodevelopmental disorders with cognitive deficits. Brain Res 760:68-73

Meltzer HY (1999): The role of serotonin in antipsychotic drug action. Neuropsychopharmacology 21(2S):106S-116S

Mezey E, Leranth C, Brownstein MJ, Friedman E, Krieger DT, Palkovits M (1984): On the origin of the serotonergic input to the intermediate lobe of the rat pituitary. Brain Res 294:231-237

Millhorn DE, Hokfelt T, Verhofstad AA, Terenius L (1989): Individual cells in the raphe nuclei of the medulla oblongata in rat that contain immunoreactivities for both serotonin and enkephalin project to the spinal cord. Exp Brain Res 75(3):536-542

Moga MM, Moore RY (1997): Organization of neural inputs to the suprachiasmatic nucleus in the rat. J Comp Neurol 389:508-534

Moller M (1976): The ultrastructure of the human fetal pineal gland. II. Innervation and cell junctions. Cell Tissue Res 169(1):7-21

Mollgard K, Wiklund L (1979): Serotoninergic synapses on ependymal and hypendymal cells of the rat subcommissural organ. J Neurocytol 8(4):445-467

Molliver ME (1987): Serotonergic neuronal systems: What their anatomic organization tells us about function. J Clin Psychopharm 7:3-23

Moukhles H, Bosler O, Bolam JP, Vallee A, Umbriaco D, Geffard M, Doucet G (1997): Quantitative and morphometric data indicate precise cellular interactions between serotonin terminals and postsynaptic targets in rat substantia nigra. Neuroscience 76(4):1159-1171

Napoleone P, Sancesario G, Amenta F (1982): Indoleaminergic innervation of rat choroid plexus: A fluorescence histochemical study. Neurosci Lett 34:143-147

Nicholas AP, Pieribone VA, Arvidsson U, Hokfelt T (1992): Serotonin-, substance P- and glutamate/aspartate-like immunoreactivities in medullo-spinal pathways of rat and primate. Neuroscience 48(3):545-559

Nishi M, Poblete JC, Whitaker-Azmitia PM, Azmitia EC (1996): Brain derived neurotrophic factor and S100ß; trophic interactions on cultured serotonergic neurons. Neurosci Net 10003 (www.neuroscience.com)

Nobin A, Baumgarten HG, Bjorklund A, Lachenmayer L, Stenevi U (1973): Axonal degeneration and regeneration of bulbo-spinal indolamine neurons after 5,6-dihydroxytryptamine treatment. Brain Res 56:1-24

Owens MJ, Nemeroff CB (1994): Role of serotonin in the pathophysiology of depression: Focus on the serotonin transporter. Clin Chem 40(2):288-295

Pecci Saavedra J, Brusco A, Peressini S, Oliva D (1986): A new case for a presynaptic role of dendrites: An immunocytochemical study of the $\mathrm{n}$. raphe dorsalis. Neurochem Res 11:997-1009

Pelletier G, Leclerc R, Dupont A (1977): Electron microscope immunohistochemical localization of substance $P$ in the central nervous system of the rat. J Histochem Cytochem 25(12):1373-1375

Pelletier G, Steinbusch HW, Verhofstad AA (1981): Immunoreactive substance $P$ and serotonin present in the same dense-core vesicles. Nature 293:71-72

Peroutka SJ, Howell TA (1994): The molecular evolution of $\mathrm{G}$ protein-coupled receptors: Focus on 5-hydroxytryptamine receptors. Neuropharmacology 33:319-324

Pickel VM, Joh TH, Reis DJ (1978): Immunocytochemical evidence for serotonergic innervation of noradrenergic neurons in nucleus locus ceruleus. In Garattini $S$ et al. (eds), Interactions Between Putative Neurotransmitters in the Brain. Monographs of the Mario Negri Institute for Pharmacological Research. Milan, NY, Mario Negri Institute, pp. 369-382

Rapport MM, Green AA, Page IH (1948): Serum vasoconstrictor (serotonin). IV. Isolation and characterization. J Biol Chem 176:1243-1251

Rodrigo J, Springall DR, Uttenthal O, Bentura ML, AbadiaMolina F, Riveros-Moreno V, Martinez-Murillo R, Polak JM, Moncada S (1994): Localization of nitric oxide synthase in the adult rat brain. Philos Trans R Soc Lond B Biol Sci 345:175-221

Saxena PR, Tangri KK, Bhargava KP (1966): Identification of acetylcholine, histamine, and 5-hydroxytryptamine in Girardinia heterophylla (Decne). Can J Physiol Pharmacol 44:621-627 
Scheibel MS, Tomiyasu U, Scheibek AB (1975): Do raphe nuclei of the reticular ormation have a neuroscretory or vascular sensor function? Exp Neurol 47:316-329

Segal M (1979): Serotonergic innervation of the locus coeruleus from the dorsal raphe and its action on responses to noxious stimuli. J Physiol (Lond) 286:401-415

Selye H (1956): The Stress of Life. New York, McGraw-Hill

Sharif NA, Towle AC, Burt DR, Mueller RA, Breese GR (1989): Cotransmitters: Differential effects of serotonin (5-HT)-depleting drugs on levels of 5-HT and TRH and their receptors in rat brain and spinal cord. Brain Res 20(480):365-371

Skinner K, Fields HL, Basbaum AI, Mason P (1997): GABAimmunoreactive boutons contact identified OFF and ON cells in the nucleus raphe magnus. J Comp Neurol 378:196-204

Smith TA (1971): The occurrence, metabolism and functions of amines in plants. Biol Rev Camb Philos Soc 46:201-241

Steinbusch HWM (1981): Distribution of serotonin-immunoreactivity in the central nervous system of the rat cell bodies and terminals. Neuroscience 4:557-618

Storga D, Vrecko K, Birkmayer JG, Reibnegger G (1996): Monoaminergic neurotransmitters, their precursors and metabolites in brains of Alzheimer patients. Neurosci Lett 12(203):29-32

Takagi H, Yamamoto K, Shiosaka S, Senba E, Takatsuki K, Inagaki S, Sakanaka M, Tohyama M (1981): Morphological study of noradrenaline innervation in the caudal raphe nuclei with special reference to fine structure. J Comp Neurol 203(1):15-22

Tao-Cheng JH, Zhou FC (1997): Serotonin transporter is distributed on the plasma membrane along the axon but not the soma or dendrite in the rat brain. Abstr Soc Neurosci 23:162-171

Twarog BM, Page IH (1953): Serotonin content of some mammalian tissues and urine and a method for its determination. Am J Physiol 175:157-161

Uhl GR, Goodman RR, Snyder SH (1979): Neurotensin-containing cell bodies, fibers and nerve terminals in the brain stem of the rat: immunohistochemical mapping. Brain Res 167(1):77-91

Ulfhake B, Arvidsson U, Cullheim S, Hokfelt T, Brodin E, Verhofstad A, Visser T (1987): An ultrastructural study of 5-hydroxytryptamine-, thyrotropin-releasing hormone- and substance P-immunoreactive axonal boutons in the motor nucleus of spinal cord segments L7-S1 in the adult cat. Neuroscience 23:917-929

Van Bockstaele EJ, Cestari DM, Pickel VM (1994): Synaptic structure and connectivity of serotonin terminals in the ventral tegmental area: potential sites for modulation of mesolimbic dopamine neurons. Brain Res 647(2):307-322

Van Bockstaele EJ, Chan J (1997): Electron microscopic evidence for coexistence of leucine-enkephalin and gamma aminobutyric acid in a subpopulation of axon terminals in the rat locus coeruleus region. Brain Res 746:171-182

Van Hartesveldt C, Moore B, Hartman B (1986): Transient midline raphe glial structure in the developing rat. J Comp Neurol 253:175-184

Verhofstad AA, Steinbusch HW, Penke B, Varga J, Joosten HW (1981): Serotonin-immunoreactive cells in the superior cervical ganglion of the rat. Evidence for the existence of separate serotonin- and catecholamine-containing small ganglionic cells. Brain Res 212:39-49

Voutsinos B, Chouaf L, Mertens P, Ruiz-Flandes P, Joubert Y, Belin MF, Didier-Bazes M (1994): Tropism of serotonergic neurons towards glial targets in the rat ependyma. Neuroscience 59(3):663-672

Wallace JA, Lauder JM (1983): Development of the serotonergic system in the rat embryo: An immunocytochemical study. Brain Res Bull 10:459-479

Wang QP, Guan JL, Nakai Y (1996): Electron microscopic study of GABAergic synaptic innervation of neurotensin-immunoreactive neurons in the dorsal raphe nucleus. Brain Res 730:118-124

Westlund KN, Krakower TJ, Kwan SW, Abell CW (1993): Intracellular distribution of monoamine oxidase $\mathrm{A}$ in selected regions of rat and monkey brain and spinal cord. Brain Res 612:221-230

Whitaker-Azmitia PM (1999): The discovery of serotonin and its role in neuroscience. Neurpsychopharmacology 21(2S):2S-8S

Whitaker-Azmitia PM, Borella A, Raio N (1995): Serotonin depletion in the adult rat causes loss of the dendritic marker MAP-2. A new animal model of schizophrenia? Neuropsychopharmacology 12:269-272

Whitaker-Azmitia PM, Wingate M, Borella A, Gerlai R, Roder J, Azmitia EC. (1997): Transgenic mice overexpressing the neurotrophic factor S-100 beta show neuronal cytoskeletal and behavioral signs of altered aging processes: Implications for Alzheimer's disease and Down's syndrome. Brain Res 776:51-60

Whitaker-Azmitia PM, Murphy RB, Azmitia EC (1990): S-100 protein release from astrocytic glial cells by stimulation of $5-\mathrm{HT}_{1 \mathrm{~A}}$ receptors and regulates the development of serotonergic neurons. Brain Res 528:155-158

Wiklund L, Sjolund B, Bjorklund A (1981): A morphological and functional studies on the serotoninergic innervation of the inferior olive. J Physiol (Paris) 77:183-186

Wilson CC, Faber KM, Haring JH (1998): Serotonin regulates synaptic connections in the dentate molecular layer of adult rats via 5-HT1a receptors: evidence for a glial mechanism. Brain Res 782:235-239

Woolley DW (1961): The Biochemical Basis of Psychosis. New York, NY, John Wiley and Sons, Inc

Yan W, Wilson CC, Haring JH (1997): 5-HT1a receptors mediate the neurotrophic effect of serotonin on developing dentate granule cells. Brain Res Dev Brain Res 98(2):185-190

Zou XC, Ho RH, Wang XM, Martin GF (1996): Evidence for GAP-43 within descending spinal axons in the North American opossum, Didelphis virginiana. Brain Behav Evol 47:200-213 